\title{
Legal Subject Interpretation of Law Number 18 of 2013 Concerning the Prevention and Eradication of Forest Destruction
}

\author{
Ahmad Sofian ${ }^{1, *}$, Batara Mulia Hasibuan ${ }^{2}$ \\ 1,2 Business Law Program, Faculty of Humanity \\ Universitas Bina Nusantara (BINUS University) \\ *corresponding author Email: asofian@binus.edu
}

\begin{abstract}
Law Number 18 Year 2013 concerning the Prevention and Eradication of Forest Destruction (Law 18/2013) specifically regulates crimes committed by organized individuals and corporations. The definition of being organized is clearly regulated in Law 18/2013. However, it is still inaccurate. Thus, this research analyzes the interpretation of criminal legal subjects regulated in the criminal provisions of Law 18/2013 and in Court Decision Number 11/Pid.Sus/2018/PN Wns. By using the normative legal research method, with legislation and case approach, it can be concluded that the legal subject intended by Law 18/2013 is an organized individual and corporation.
\end{abstract}

Keywords: criminal liability, legal subject, law 18/2013

\section{INTRODUCTION}

There has been an increasing trend in forest destruction cases caused by forest utilization and the use of forest areas in a manner which is inconsistent with the provisions of law or provisions of laws and regulations. Frequent destruction of forests occurs in the form of illegal logging, and the unauthorized exploitation of forest areas. Forest destruction does not only occur in production forest areas; rather, it has also begun to occur in protected forest areas and conservation forests [1].

Rampant crimes of systemic forest destruction committed by corporations and organized groups have lead to calls to draft laws that specifically regulate organized crime and crimes committed by corporations, namely Law of the Republic of Indonesia Number 18 Year 2013 Concerning the Prevention and Eradication of Forest Destruction (P3H Law). This law clearly refers to the subject of offence of more than one person acting jointly and in a structured manner, and corporation as subject of offence.

Law of the Republic of Indonesia Number 18 of 2013 concerning the Prevention and Eradication of Forest Destruction often criminalizes local communities who are simply undertaking activities following the rotational traditions established by their groups, or it even criminalizes people living around forests who gather forest products for their livelihood. The P3H Law can be deemed as a product of inferior legislation and it cannot serve as a solution to the issue it aims to regulate in an exhaustive manner. At the same time, the establishment of the P3H Law was originally aimed to eradicate and prevent forest destruction by corporations and organized groups which are becoming increasingly massive in their numbers by the day.

This research is based on the interpretation of the legal subject set out in the definition of P3H Law, namely organized individuals and individuals. There is frequent erroneous application of the articles used by the Public Prosecutor as a basis for the charges against the legal subject as set out in the P3H Law. In the case used by the author, the legal subject to be charged is an individual, while the legal subject referred to in the $\mathrm{P} 3 \mathrm{H}$ Law is person(s) acting on behalf of an organized association or on behalf of a corporation. Incomprehension or misinterpretation of the subject of law can have fatal consequences.

This law is intended for crimes committed by organized actors or corporations, while in the case study of the Decision of Soppeng District Court No. 11 / Pid.Sus/2018/ PN Wns, the subject of offence in the indictment filed by the Public Prosecutor are the Farmers working individually. The Farmers who are the subject of offence in the indictment in the case with the Decision of the Soppeng District Court No. 11/Pid.Sus/2018/PN.Wns were carrying out their work individually without knowing each other, at different places, were not organized in any form whatsoever. and neither did they belong to a certain corporation or company. 
It is expected that this research will invite the attention of law enforcement, especially the Public Prosecutor, to a more thorough understanding of the definition or general elucidation on Article 1 in order to avoid erroneous determination of the subject of offence for the purpose of indictment, because as the above case indicates, the juridical requirements of subject of offence were not fulfilled hence the panel of judges acquitted the defendants.

\section{ELABORATION AND DISCUSSIONS}

In $\mathrm{P} 3 \mathrm{H}$ Law there are two categories of legal subjects, namely individuals and corporations. As mentioned in Article 1 Sub-article 21 of P3H Law concerning the definition of any person ('setiap orang'), there are two distinct categories, namely: 1) Individuals; and 2) Organized individuals. The subject of law is also mentioned in several other articles in the $\mathrm{P} 3 \mathrm{H}$ Law. The meaning of the word "organized" is also defined in Article 1 Sub-article 6 of the P3H Law. Hence, in general, the P3H Law focuses on an activity carried out in an organized manner.

Furthermore, the table below describes 10 (ten) provisions, ranging from the consideration, the substance of the articles up to the General Elucidation concerning the legal subject of organized individuals, including the following among other things:

TABLE 1 Provisions on the Definition of Legal Subjects in Law P3H

\begin{tabular}{|c|c|c|}
\hline No. & Provisions & Contents \\
\hline 1. & Considerations of P3H Law item (e) & $\begin{array}{l}\text { The destruction of forests is a crime of } \\
\text { extraordinary impact, organized, and cross-border } \\
\text { in nature with a sophisticated modus operandi. }\end{array}$ \\
\hline 2. & Considerations of P3H Law item (f) & $\begin{array}{l}\text { The currently existing law has not been capable } \\
\text { eradicating the organized destruction of forests. }\end{array}$ \\
\hline 3. & Article 1 Sub-article 21 & $\begin{array}{l}\text { Individuals and/or corporations carrying out forest } \\
\text { destruction in an organized manner in Indonesian } \\
\text { jurisdiction. }\end{array}$ \\
\hline 4. & Article 1 Sub-article 22 & $\begin{array}{l}\text { Corporations shall be an organized association of } \\
\text { people and/or assets. }\end{array}$ \\
\hline 5. & Article 1 Sub-article 6 & $\begin{array}{l}\text { Organized shall be activity carried out by a } \\
\text { structured group consisting of not less than } 2 \\
\text { (two) or more persons, and acting together. }\end{array}$ \\
\hline 6. & Article 1 Sub-article 4 & $\begin{array}{l}\text { Illegal logging shall be the unauthorized } \\
\text { utilization of forest products in an organized } \\
\text { manner. }\end{array}$ \\
\hline 7. & Article 1 Sub-article 5 & $\begin{array}{l}\text { Illegal use of forest areas shall be an unauthorized } \\
\text { organized activity. }\end{array}$ \\
\hline
\end{tabular}




\begin{tabular}{|c|l|l|}
\hline No. & \multicolumn{1}{|c|}{ Provisions } & \multicolumn{1}{c|}{ Contents } \\
\hline 8. & Article 11 paragraph (3) & $\begin{array}{l}\text { Structured groups shall not include communities } \\
\text { living in and/or the surroundings of forest areas } \\
\text { which conduct traditional farmland farming } \\
\text { outside conservation forest areas and protected } \\
\text { forests for their own purposes and not for } \\
\text { commercial purposes. }\end{array}$ \\
\hline 10. & General elucidation on the P3H Law & $\begin{array}{l}\text { In terms of eradicating forest destruction carried } \\
\text { out in an organized manner, because the existing } \\
\text { legislation is yet to bring optimal results. }\end{array}$ \\
\hline
\end{tabular}

Source : research result, 2020

Furthermore, in view of Court Decision Number: 11/Pid.Sus/2018/PN Wns, the indictment in this case is an alternative indictment; the first indictment in this case is Article 82 paragraph (1) sub-paragraph b jo. Article 12 Sub-article b of the P3H Law, whereas the second indictment is Article 17 Paragraph (2) sub-paragraph $\mathrm{b}$ of the $\mathrm{P} 3 \mathrm{H}$ Law.

The consideration of the Panel of Judges was stated as follows: (1) the elements of the two articles have not been fulfilled; and (2) whereas the defendant cannot be categorized as an organized individual. At the same time, the ruling of the judgment states with regards to the defendant that the defendant was not legally and convincingly guilty of having committed a criminal offence as charged in the second alternative indictment filed by the Public Prosecutor.

\subsection{Interpretation of Legal Subjects under Law No. 18 of 2013 concerning the Prevention and Eradication of Forest Destruction}

Law No. 18 of 2013 concerning the Prevention and Eradication of Forest Destruction or often referred to as the $\mathrm{P} 3 \mathrm{H}$ Law is a special criminal law, which is intended to eradicate organized forest crimes and forest crimes committed by corporations; this law is not intended to criminalize small farmers who live and settle in or around forests to undertake farming. Such reasoning is evident from the General Elucidation on this Law:

"...lately, the destruction of forests has become increasingly widespread and complex. Such destruction has been occurring not only in production forests, but also in protected forests or even conservation forests. Forest destruction has developed into a criminal act which has a tremendous impact, it is organized and involves numerous parties, both national and international. The damage caused has caused an extremely high level of concern for the survival of the nation and state. Therefore, extraordinary measures shall be taken to address the issue of forest destruction."

It is clear and evident from the general elucidation that forestry crimes intended in this law are committed by forestry syndicates, whereby it has been considered that the previous law was not capable of overcoming the ongoing extraordinary and systemic forestry crimes. Thus, it is expected that this law will be able to identify and criminalize the perpetrators of organized crime. Accordingly, the legal subject under this law are perpetrators of illegal logging who have connections with crime syndicates, perpetrators of organized crime, reaching even across borders, and it is not aimed at unorganized perpetrators not involved in syndications. Forestry crimes on a smaller scale can refer to the forestry law (Law No. 41/1999). Other authentic evidence related to this argument can found in the considerations of the $\mathrm{P} 3 \mathrm{H}$ Law as follows:

" whereas the destruction of forests, especially in the form of illegal logging, unauthorized mining, and unauthorized plantations have caused losses to the state, damage to socio-cultural and environmental life, as well as increased global warming which has become a national, regional and international issue; "whereas the destruction of forests has become a crime that has an extraordinary impact, it is organized and cross-border in nature carried out with a sophisticated modus operandi, it has jeopardized the survival of the community so that in the context 
of effective prevention and eradication of forest destruction and for the purpose of deterrent effect. there is a need for a solid legal basis and one that is able to guarantee effective law enforcement; whereas the existing legislation to date has not been adequate and it has not been capable of effectively addressing the eradication of organized forest destruction;"

The above excerpt reinforces the argument that this law is applicable only to the organized subjects of law; hence investigators should be able to ascertain in the initial stage of investigation that, when intending to use this law, there is sufficient preliminary evidence of the perpetrators of the organized crime suspected of having committed the criminal act of forest destruction. If they are not organized legal subjects, the forestry law should be applied. Organized legal subjects can be identified based on Article 1 sub-article 21 which reads as follows:

"Any person shall be an individual and/or corporation who commits organized acts of forest destruction in Indonesia jurisdictions and/or resulting in legal consequences in Indonesian jurisdictions"

The $\mathrm{P} 3 \mathrm{H}$ Law also provides an authentic interpretation of the term 'organized', namely as set out in Article 1 sub-article 6 which reads as follows: "Organized shall be an activity carried out by a structured group, consisting of 2 (two) or more persons, and acting jointly at a certain time for the purpose of destroying forests, excluding groups of people living in or in the surroundings of forest areas that carry out traditional logging and/or logging for their own purposes and not for commercial purposes"

Thus it is clear that this law is not applicable to unorganized forestry crimes, including criminal acts committed by community groups living in the surroundings of traditional forests/plantations benefiting from the forests for their livelihoods. Traditional farmers who live in the surroundings of forests or even in forests who exploit forests for their livelihood have immunity against this law, and cannot be treated as subjects of criminal offence.

As mentioned in the above brief explanation concerning the subject of law under the P3H Law, one of them is 'organized individuals'. Based on the elucidation on the P3H Law, 'any person' ('setiap orang') is an individual acting in an organized manner. In the P3H Law 'organized' means 'consisting of 2 (two) or more persons acting together', thus an organized individual is not a single person; rather than that, it implies not less than 2 (two) or more persons who commit forest destruction.

The criminal act committed by the legal subject under the $\mathrm{P} 3 \mathrm{H}$ Law involves the destruction of forests. In item e of the considerations of the $\mathrm{P} 3 \mathrm{H}$ Law it is stated that the destruction of forests is a criminal act involving a large-scale legal subject, even across borders, using a sophisticated modus operandi. Accordingly, the term 'organized' is not appropriately used in the qualification of individual and personal perpetrators of crimes.

By looking at the $\mathrm{P} 3 \mathrm{H}$ Law, it clearly articulates that 'any person' consists of 'organized individuals' and/or 'corporations'. 'Organized individuals' as legal subjects under the criminal provisions of the P3H Law are divided into two categories, namely: (1) Individuals (2) Individuals living in and/or in the surroundings of forest areas.

In the elaboration on the definition of 'organized' in Article 1 Sub-article 6 of the P3H Law it is stated that forest destruction activity has exceptions for traditional communities living in or around forest areas that carry out traditional logging and/or logging for their own purposes and not for commercial purposes. According to the General Elucidation on the P3H Law, traditional farming is an activity granted to people who have lived for generations in the forest area and conduct farm activities by following the rotation tradition that has been determined by the group concerned.

Communities that conduct recreational activities in the forest area are not included in the definition of legal subject 'any person' as intended in the $\mathrm{P} 3 \mathrm{H}$ Law. Under the P3H Law, traditional communities are among the exceptions. Traditional communities are excluded by the P3H Law when doing logging and/or felling trees for their own purposes and not for commercial purposes. To the extent that the act is undertaken with no financial benefit from the proceeds of logging or tree-felling.

The doctrine of criminal law teaches that in order for a person to be convicted of a crime, the subjective elements and objective elements must be fulfilled [2]. Subjective elements include the person and the fault, namely the person concerned is held criminally liable as legal subject for an unlawful act committed by it. In Naffine's view, a legal subject can only be held liable if the requirements as legal subject are met. As Naffine states in her writings, not all human beings are qualified or meet the requirement to be considered as a 'person', only rational and competent persons based on the law. According to said theory, competent to be held accountable means that the person concerned is not alienated by his/her 
own mind and is capable of acting in a rational manner [4].

The interpretation of legal subjects under the P3H Law has its own specificity. Legal subject as intended by the P3H Law is not identical to the legal subject intended in other laws, hence an inadequate interpretation of legal subject can result in the inability to hold the person concerned liable for his/her acts due to the public prosecutor's erroneous interpretation of the persons who belong to the category of organized individual.

\subsection{Analysis of Verdict No. 11/Pid/Sus/2018/PN Wns}

This special crime case was decided on March 21, 2018 by the Panel of Judges at Watansoppeng District Court. The first indictment, namely Article 82 paragraph (1) sub-paragraph b jo. Article 12 subarticle $b$ of the P3H Law, could not be proven, because the defendants cannot be categorized as "organized" individuals, the defendants are members of the traditional community and the felling of trees was not for commercial purposes. As for the second Indictment under Article 92 paragraph (1) subparagraph a jo. Article 17 paragraph (2) subparagraph $b$ of the $\mathrm{P} 3 \mathrm{H}$ Law it could not be proven either that the element had been fulfilled, because although the element of the defendant's fault had been apparently fulfilled, the element of legal subject was not fulfilled.

Based on the analysis of the charges in the verdict, the charges should not have been filed because the legal subject intedended in the P3H Law is not applicable to private individuals (individuals); in addition to that, traditional communities are also an exception because according to the provisions of Article 1 Sub-article 6, traditional communities living in or around forest areas do not fall into the category of "organized", hence the defendant does not belong to that category. Furthermore, following is an analysis of the consideration of the Panel of Judges and the ruling in the verdict. In its deliberations, the Panel of Judges interprets the subject of law based on a historical interpretation based on the interpretation of the P3H Law viewed as a whole, rather than a partial interpretation of portions of its articles, hence the Panel of Judges was able to conclude that the legal subject intended under the $\mathrm{P} 3 \mathrm{H}$ Law is an organized individual meaning at least 2 (two) persons [6].

In its deliberations, the Panel of Judges stated that the Public Prosecutor's indictment erroneously applied Law No. 18 of 2013 concerning the
Prevention and Eradication of Forest Destruction (Law P3H). The Public Prosecutor should have applied a law which is more relevant to the actions of the three Defendants. It is because juridically the P3H Law is specifically aimed at the crime of forest destruction carried out in an organized manner as stated in the considerations of the $\mathrm{P} 3 \mathrm{H}$ Law. At the same time, the facts revealed at the trial prove that the three Defendants were merely traditional farmers who cut down trees and engaged in farming solely for fulfilling the need for clothing, food and shelter.

The meaning of 'any person' referred to in the P3H Law as charged against the three Defendants is an organized individual. At the same time, the actions of the three Defendants were not carried out in an organized manner. Therefore, the element of 'any person' charged against the three Defendants is not fulfilled; their actions are included under the qualifications set out in the general provisions of Article 1 of the P3H Law, namely Article 1 subarticle 6 which contains impunity for farmers who have lived for many generations in or around forest areas who cut down trees or engage in traditional farming, not for commercial purposes.

The Panel of Judges' view is certainly in line with the values adopted by the $\mathrm{P} 3 \mathrm{H}$ Law. In interpreting the offence provided for in the law concerning law enforcement (the police and prosecutors), it cannot be viewed partially; rather, it has to be considered in an integral manner. In considering offences (prohibited acts) under a law, the philosophical basis and historical basis for the establishment of the law concerned must also be duly taken into account, which can be seen from the considerations and general elucidations on the law. In addition to the above, the legal principles adopted in the law should also be considered, which is generally set out in Article 1 .

\section{CONCLUSION}

Based on the above discussion of research results, the following conclusions can be drawn:

1. Based on the interpretation of legal subject in the criminal provisions under the $\mathrm{P} 3 \mathrm{H}$ Law, there are three types of legal subject, namely: Organized individuals, organized individuals living in and/or around forest areas, and corporations; in interpreting legal subjects, the articles of the law concerned should be viewed as a whole. Considering that $\mathrm{P} 3 \mathrm{H}$ Law is a special law, it needs to be considered from all perspectives, not only through the criminal provisions of the $\mathrm{P} 3 \mathrm{H}$ Law but also based on the purpose of the establishment of the P3H Law. It is to minimize 
the cases of criminalization of communities living around/in the forest often subjected to the P3H Law which was in fact adopted not to target such communities; rather than that, it is aimed at 'organized individuals'.

2. In its considerations, the Panel of Judges explained that in fact the element of 'any person' in this case needs to be proven based on the purpose for adopting the $\mathrm{P} 3 \mathrm{H}$ Law, namely by using the method of interpretation of the reason for the establishment of the $\mathrm{P} 3 \mathrm{H}$ Law. Furthermore, it refers to the considerations of the Panel of Judges who interpreted that the legal subject intended by the $\mathrm{P} 3 \mathrm{H}$ Law is an "organized individual" who actually consists of at least 2 (two) persons or more and not a community living in or around the forest and cutting down trees which is not for commercial purposes. The tribunal ruled the three defendants did not meet the qualification as legal subject, so they had to be acquitted. The defendants are not perpetrators of organized forest destruction crimes as intended in the $\mathrm{P} 3 \mathrm{H}$ Law.

\section{ACKNOWLEDGMENTS}

The Authors wish to acknowledge the assistance or encouragement from colleagues, especially work by technical staff and financial support from BINUS University.

\section{REFERENCES}

[1] Illegal logging is defined as all activities of unauthorized utilization of timber forest products. (Constitutional Court, Decision of the Constitutional Court judicial review of Law No. 18 of 2013 concerning the Prevention and Eradication of Forest destruction and Law No. 41 of 1999 concerning Forestry against the 1945 Constitution of the Republic of Indonesia, Decision No. 95/PUU-XII/2014, p. 159.

[2] Moeljatno, Basic Principles of Criminal Law. Jakarta : Rineka Cipta, 2002, p. 54.

[3] Ngaire Naffine, "Who are Law's Persons? From Cheshire Cats to Responsible Subjects." in Modern Law Review. Vol. 66. No. 3. 2003. pp. 346-367. Quoted from Nani Mulyati, Corporation as the Subject of Law and Criminal Accountability in Indonesian Criminal Law," (Doctoral Dissertation, University of Indonesia, Jakarta 2017), p. 32.

[4] Ngaire Naffine, "Who are Law's Persons? From Cheshire Cats to Responsible Subjects." in the Modern Law Review. Vol. 66. No. 3. 2003. pp. 346-367. Quoted from Nani Mulyati,
Corporation as The Subject of Law and Criminal Accountability in Indonesian Criminal Law," (Doctoral Dissertation of Universitas Indonesia, Jakarta 2017), p.37.

[5] Jan Remmelink, Criminal Law, (Jakarta: Gramedia Pustaka Utama, 2003), pp 97-109.

[6] C.S.T. Kansil, Introduction to the Science of Law, (Jakarta: Balai Pustaka, 2002), pp. 36-41. 